\title{
THE FATHER'S ROLE IN UPBRINGING - RESOURCES AND OBSTACLES OF CONTEMPORARY FATHERHOOD
}

\author{
Pavol Janoško', Erika Janušková ${ }^{1}$ \\ ${ }^{1}$ Mgr, Ph.D., Faculty of Education, Comenius University in Bratislava, SLOVAKIA, \\ janosko2@uniba.sk \\ ${ }^{2}$ Mgr, Faculty of Education, Comenius University in Bratislava, SLOVAKIA, januskova7@uniba.sk \\ ${ }^{*}$ Corresponding Author
}

\begin{abstract}
The paper deals with the role of the father in upbringing in the context of the family environment. Unlike in Slovakia, several more comprehensive research investigations have taken place abroad and a larger number of relevant publications are available (MPSV ČR, 2010; McLaughlin and Muldoon, 2014; Miller, 2011; Vreeswijk et al., 2014; John et al., 2005). The aim of the presented research was to examine the attitudes and opinions of current fathers on the role of the father in the family, upbringing of children and division of parental roles, and to identify the degree of involvement of current fathers in upbringing, childcare and activities with children. Also identify any obstacles that current fathers face in fulfilling their role and how they perceive their own fatherly role. From a methodological point of view, it was a model of mixed, quantitative-qualitative research design. Given the stated objectives of the survey and the current pandemic situation, the authors chose a questionnaire as the method of data collection. For its preparation, we relied on a sociological research entitled Forms of Fatherhood in the Czech Republic, which was part of a two-year public information campaign to support paternity carried out by the Ministry of Labor and Social Affairs of the Czech Republic (MPSV CR, 2010). The survey sample consisted of men - fathers, who had to meet two conditions. The first concerned the age of the child (children) (at least one minor). The second condition was that the fathers lived in the territory of the Slovak or Czech Republic at the time of the survey due to the organization of the survey within these territories. The age groups of fathers 40-49 and 30-39 were the most represented in the research sample $(n=151)$. The vast majority of our fathers were employed. Almost all fathers grew up in a family with a father and mother, and three-quarters of fathers were married for the first time. Most fathers had two children, just behind the most marked option was one child. The most represented age category of children was 6-10 years. The study was created as part of the KEGA project no. 002UK-4/2020 (MŠVVaŠ SR), Faculty of Education, Comenius University in Bratislava, Department of Therapeutical Education.
\end{abstract}

Keywords: Father, child, role of father, upbringing and care, current fatherhood, resources, obstacles of fatherhood.

\section{INTRODUCTION}

Like motherhood, fatherhood has new challenges and brings something special and important to the child's 
life. On their journey to parenthood, fathers (like mothers) face obstacles, challenges and difficulties, but also joy, amazement and enthusiasm for a new role in life. It is a long and complex process, not an event. It represents learning new things, changing lifestyle and also higher demands on personal growth. According to Crespi and Ruspini (2015, p. 355), "Becoming a father" is a complex state of being that requires changes in the emotional area as well as in the lifestyle, and it takes time." The factors that affect this process are the father 's age, economic background, employment, relationship with his own parents, relationship with a partner, etc. They influence how a man accepts his role as a father, to what extent he will take an interest in the child and get involved in it, and also how he will get a picture of what his role as a father is.

The new offspring represents the amount of new information that fathers need to receive, as well as the amount of new skills and activities they need to acquire. With the current changes in the understanding of fatherhood, naturally comes the knowledge that the ability to care for a child is not something specifically feminine. Both women and men have this opportunity. The fact that men do not take care of a child (they do not want to, cannot) does not mean that they are not potentially capable of that. It is also true that a person is not born to parents, but becomes, when he enters into a relationship with the child, is permanently with the child, takes care of the child and takes responsibility for the child's well-being - regardless of the parent's gender (Maříková, 2008b). It is important for the father to make contact with the baby before birth. According to Vreeswijk et al. (2014) Fathers who reported higher and better attachment rates were more likely to have a balanced image of the child, while fathers with a lower level of attachment tended to have unbiased, emotionally distant images of the child, which may naturally affect mutual relationship even after birth.

When men become fathers, they go through external lifestyle changes as well as an internal personal transformation process. They imagine themselves as a father, their perceptions of themselves change. They feel more responsible, wiser, more mature. As part of external change, fathers' attitudes towards employment are also changing and they feel that they will have to change their lives more fundamentally and reassess their priorities (Miller, 2011). According to a study by Nešporova (2019), in anticipation, fathers thought a lot about changes in employment - changes in working hours, habits - so that they could be more at home and help with the child or, conversely, plan to work more to provide better for the family. They also mentioned that they would have less time for their hobbies. They did not plan to give them up completely, but reckoned that they would have to adapt in this area as well.

\section{CRITICAL EVENTS RELATED TO SECONDARY ATTACHMENT WITH THE FATHER}

The father's relationship with the child is the second key relationship in his life. It is a secondary relationship that plays an important role not only in supporting a quality attachment between mother and child, but also in the process of separation from the mother (response to the child's evolving need for autonomy), independence and openness to the world. Not only the quality of the relationship between the child and the secondary relationship person, but also the mother's relationship and trust in the father play an important role here. She is the one who invites the father into this relationship and the child "passes on" to him. Difficulties arise if the separation of the child comes too soon, before the child is ready for the stage. This can be manifested by anxiety and instability, slow development, development of aggressive behavior, symptoms of attention deficit hyperactivity disorder in the child, etc. The reason may be disagreements between partners or the mother's fear of separation, which often has roots in her basal family triad. In the context of accompanying a family in crisis, it is interesting to note that Trapková and Chvála (2004) managed to prove that families in which they also acquired a father for cooperation overcame the crisis and recovered much faster and more reliably than those where the father was missing or stayed without emotional contact and did not participate in the treatment process.

Despite all efforts, difficulties and critical moments in the life of any family cannot be avoided. They test how individual members manage a given situation, such as the quality of relationships and mutual ties in the family, how the family is able to withstand the onslaught of the burden in which it finds itself. Critical events related to secondary attachment include, for example:

Table 1. Critical events related to secondary attachment - father and child

The man does not This may be due to the uncertainty of the father, the failure to manage his father's support the role in the family, or the avoidance of gradually taking responsibility for raising the separation of the child. If the child's separation is not supported, the child cannot build a healthy woman from the child relationship with himself and this can significantly negatively affect his trust in others and establishing relationships with other people (peers, teachers, etc.). 
Neglect of the couple relationship between the partners

This is the risk that the partners are exposed to by taking on the new role of parents, which they prefer to the role of partner. After conceiving a child, it is natural for attention to be focused on him and his needs. However, one parent may feel isolated. It helps to remember that the foundation of every functional family is a partnership. The overall climate in the family, whether the children feel loved and safe there depend on its quality.

Faithlessness

It concerns each of the partners. This is a serious interference with the parents' partnership, which often leads to the breakdown of the marriage (as well as the family concept) and a significant disruption of family cohabitation. The impact of the problem depends on the nature of the infidelity as well as the ability of the partners to face the problem. Children usually perceive the disruption of their parents' partnership very painfully, as there is a strong bond between them and their parents (although this may not seem like it on the outside). It leads to chaos in survival, the inability to decide which parent to side with. They lack the presence of a stable person to help them understand and manage the situation and deal with the feelings they experience.

Different forms of The addiction of one parent (in the worst case of both) leads to great addiction destabilization of the family as such. Under the influence of the addictive substance, the parent is not able to provide family functions, and the other parent becomes overwhelmed. Children suffer in all aspects. The atmosphere in the family is constantly tense. There is a constant expectation of something bad (that something bad will happen). The child lives in constant stress, experiencing frequent feelings of shame. He can either close in on himself, become introverted without interest in social contacts, or become overly responsible, take on the responsibilities of a parent and look without problems. In reality, however, he suffers greatly, which can later turn into aggression against himself (self-harm) or others.

Loss of relationship intimacy and closeness in childhood is considered the basis and reason for the so-called habitual coping patterns that have a negative effect on self-knowledge and self-esteem. Awareness of these patterns and how to deal with them can lead to adult congruence, an authentic relationship with oneself, and the ability to establish meaningful and intimate relationships with others (Lewis, Banmen, 2009).

\section{RESEARCH REPORT: CURRENT FORMS OF FATHERHOOD}

Under the influence of social and cultural changes, more attention is beginning to be paid to the study of fatherhood. Unlike in Slovakia, several more comprehensive research investigations have taken place abroad and a larger number of relevant publications are available (MPSV ČR, 2010; McLaughlin and Muldoon, 2014; Miller, 2011; Vreeswijk et al., 2014; John et al., 2005). The aim of our survey was to offer an insight into the situation of fathers today in Slovakia and the Czech Republic and to contribute to a higher awareness of the topic of fatherhood in both the professional and lay public.

\subsection{Research Objectives}

The main goal: $\quad$ to identify the current forms, resources and obstacles of paternity in fathers living in Slovakia and the Czech Republic.

Sub-objectives:

Find out the attitudes and opinions of current fathers on the role of the father in the family, the upbringing of children and the division of parental roles.

Identify the degree of involvement of current fathers in upbringing, childcare and activities with children.

Find out whether current fathers are more inclined to "traditional" or "modern" fatherhood. 
Proceedings of INTCESS 2022- 9th International Conference on Education \& Education of Social Sciences 17-18 January 2022- Online Conference

Identify possible obstacles that current fathers face in fulfilling their role.

Find out how current fathers perceive their own fatherly role.

\subsection{Methods}

From a methodological point of view, we used a mixed research model, resp. quantitative-qualitative research design. Given the stated objectives of the survey and the current pandemic situation, we chose a questionnaire as the method of data collection. For its preparation, we relied on sociological research entitled Forms of Fatherhood in the Czech Republic, which was part of a two-year public information campaign to support paternity conducted by the Ministry of Labor and Social Affairs of the Czech Republic and ran from October 2009 to February 2010 (European Social Fund in the Czech Republic). The questionnaire was created in electronic form and distributed using a web link. We largely addressed the potential respondents directly, but we also used the publication on the social network and in internet groups. Several answers were also obtained through the so-called "Snowball sampling" methods, where the addressed respondents forwarded the questionnaire to other respondents. The collection of responses took place from January to March 2021.

The research sample consisted of men - fathers, who had to meet two conditions. The first concerned the age of the child (children) (at least one minor). This restriction was intended to ensure that the sample consisted of current and active fathers on whom our survey focused. The second condition was that the fathers lived in the territory of the Slovak or Czech Republic at the time of the survey due to the organization of the survey within these territories.

\subsection{Results}

The age categories of fathers 40-49 and 30-39 were the most represented in our research sample $(n=151)$. The vast majority of our fathers were employed. Almost all fathers grew up in a family with a father and mother, and three-quarters of fathers were married for the first time. Most fathers had two children, just behind the most marked option was one child. The most represented age category of children was 6-10 years.

$92 \%$ of fathers lived in the same household as their partner and children, and most fathers had higher incomes than their partner. During working days, fathers most often spent 1-3 hours a day with their children, and more than 6 hours a day on weekends. We found that fathers were actively involved in various activities related to family life and children, most notably in financially securing the family, buying groceries, and devising a weekend program.

$62.9 \%$ of fathers were in favor of a stricter upbringing style. On the issue of upbringing, it was very important for fathers to maintain authority in the family and at the same time to have a friendly relationship with the children. They also wanted to give their children as much time as possible, but it was important for them to find time for themselves as well. More than $62 \%$ of fathers believe that small corporal punishment are not harmful.

Respondents also supported a fair division of responsibilities between father and mother and were able to imagine themselves in "typically female" positions such as parental leave. $72.9 \%$ of fathers would be willing to stay on parental leave under certain circumstances. At the same time, however, more than half of fathers $(53 \%)$ considered the mother to be a more competent person who should remain on parental leave. When it comes to employment, the vast majority of fathers had no problem reconciling family and work life, and their employer met their family affairs.

$92.7 \%$ of fathers were on ultrasound during pregnancy and $80.8 \%$ were present at childbirth. After birth, up to $98 \%$ of fathers were actively involved in caring for a young child, and we found that they performed almost all of the child care activities on a daily basis (feeding, changing, sleeping, etc.).

Almost three quarters of fathers $(72.2 \%)$ were satisfied with how much time they devoted to their children. Unsatisfied fathers cited workload as the most common obstacle. Even in their free time, fathers actively and regularly cared for their children, chatting and playing with toys on a daily basis and going on trips, walks or playing sports on a weekly basis.

The last question in the questionnaire was open and voluntary. We asked our fathers: What does fatherhood mean to you, how has it affected (changed) you? We obtained answers from 125 fathers $(n=125)$, in which we identified several qualities and dimensions of fatherhood, which we categorized as follows: 
We "cleaned up" the significant propositions (categories) that arose during the retelling so that they made sense, and then we compiled a dynamic scheme of these propositions.

Proposition scheme:

\begin{tabular}{|c|c|c|c|}
\hline change & - fulfillment & commitment & source of learning \\
\hline & challenging task & responsibility & meaningfulness \\
\hline
\end{tabular}

On the propositional scheme we can tell the basic story of our more detailed qualitative analysis: When a man becomes a father, it represents a fundamental change that affects his personality at all levels - physical, mental, social and spiritual. This change leads to deep feelings in the fathers' inner fulfillment, but also to concerns and doubts as to whether they are or will be able to cope with the many difficult tasks associated with fulfilling father's responsibilities as well as responsibilities in a partnership. However, fathers perceive this role as a mission, which leads them to an inner commitment and responsibility for the roles and challenges that fatherhood brings. Ultimately, for our sample, this new state is an important source of learning and gives them a sense of greater meaning in their existence.

\section{DISCUSSION}

Regarding the attitudes and opinions of current fathers on the role of the father in the family, the upbringing of children and the division of parental roles, up to $93.4 \%$ of fathers agreed that the father should represent a certain authority in the family. At the same time, however, survey respondents largely considered it important to be friends and partners for children. The same results were demonstrated in the research Forms of Fatherhood in the Czech Republic, while the authors of the research called it a discrepancy and ambiguity in the definition of paternal role (MPSV ČR, 2010). Thus, for the fathers, authority in the family was important, but not in the sense of a strict patriarch who required unconditional obedience. It is clear from the answers that they currently care about a closer relationship with the child. On the other hand, more than $60 \%$ of fathers were in favor of a stricter upbringing style and also emphasized compliance with the rules and limits in upbringing. We also found that fathers no longer considered financial security (family care) to be their most important role in a child's life, but agreed that it was best for children to give them as much time as possible. In the area of the division of parental roles, fathers promoted equality, a fair division of responsibilities between mother and father, as well as the partner's right to self-realization. Rather, they did not agree with the traditional division of labor, where the mother takes care of the household and the children and the father is mainly engaged in making money and only playing with the children. An interesting finding, however, was that more than half of the fathers considered the mother to be an irreplaceable person for a child aged 2 to 4 years and thought that she should rather remain on parental leave. Up to two thirds of fathers held this view in the study Forms of Fatherhood in the Czech Republic (MPSV ČR, 2010). Maybe that was one of the reasons why we find so few fathers on parental leave in our society. At the same time, in other countries it is common practice for a father to remain with a small child.

Our survey confirmed the assumption that current fathers are actively involved in parenting, childcare and childcare activities. Almost half of the fathers are involved in housework such as cleaning and ironing, preparing food and planning family activities. $82.7 \%$ of fathers buy food. Fathers also take care of children sleeping, hygiene and organizing the child's free time. As many as $98 \%$ of our fathers were actively involved in caring for a newborn / child at an early age. They performed activities such as feeding, changing, bathing or walking on a daily basis.

One of our sub-goals was for "traditional" and "modern" fatherhood. We identified attitudes towards authority, time spent with children, attitudes towards the role of the father in the family and an understanding of the role of father and mother in the family as distinguishing factors. We have defined a traditional father as one who prefers authoritarian upbringing, does not spend too much time with children, considers securing the family as his main role and prefers a traditional division of roles, where the mother takes care of the household and the children and the father earns. The traditional father is closer to the models of a strict patriarch and a distant breadwinner, as described by Pleck and Pleck (1997). We consider a modern father to be one who seeks a close relationship with the child, spends a lot of time with children, actively participates in matters of family life and child care, and promotes an equal division of parental and family responsibilities between mother and father. This father is closer to the models of the involved father and co-parent (Pleck and Pleck, 1997). 
During working days, fathers spend 1-3 hours a day with their children, on weekends it is more than 6 hours a day for almost half of fathers. At the same time, fathers have largely agreed that time is the best they can give their children and that the right father devotes his free time primarily to children. We found that $89.2 \%$ of fathers identified the family's financial security as one of the activities in which they are most involved, but at the same time only $33.8 \%$ of fathers consider this activity to be the best they can do for children. Fathers were also very active in caring for a young child and regularly engaged in joint activities with children. Less than half of the fathers were involved in housework. The traditional division of labor was supported by $42.2 \%$ of fathers, but as many as $95.3 \%$ of fathers agreed that their partner had the same right to be realized. From the above, we can conclude that it is not clear whether the fathers leaned more towards traditional or modern fatherhood. The results indicate the occurrence of both models in our society and we could say that we are on the border between the two models. Our results correspond to the results of the research Forms of Fatherhood in the Czech Republic, where this situation was named as a "period of transition from traditional fatherhood to the modern concept and perception of fatherhood" (MPSV ČR, 2010, p. 5).

Our next sub-objective was to identify any obstacles that current fathers face. We recognized several of them. Although up to $91.4 \%$ of fathers did not find themselves at a disadvantage compared to mothers, those who encountered it mentioned the mother as a preferred person for children and divorces. Fathers who were dissatisfied with how much time they spent with their children were most often mentioned as an obstacle to workload. Half of fathers also feel that they have less time for children because of work. The child's mother and the lack of support from her, as well as the fact that the child did not live with the father in the same household, were also an obstacle in spending time with the child.

Regarding the respondents' perception of their own fatherly role, we identified several characteristics of fatherhood that were often repeated in the responses. Above all, it is the joy and happiness that children bring to fathers, but it goes hand in hand with responsibility and commitment. Fathers often mentioned these two characteristics of fatherhood together. We have also found that fathers feel the difficulty of parenthood, which also brings with it restrictions and less free time. Many fathers wrote that fatherhood meant a change for them in several areas. They perceived it as a great change in life, a new dimension of life and a meaning to life. There have also been changes in fathers' priorities and values. In the first place, they gave the child and the right upbringing. Last but not least, the fathers themselves changed, they began to perceive life differently, they became more aware of their actions and their influence on the child. According to the fathers, fatherhood is also a space for learning: patience, gratitude, humility and much more. As a final characteristic, we identified in our responses the perception of fatherhood as a mission, a way of life and a role that is part of life. Our results correspond to the findings of Miller (2011), Maříková (2008a) and Nešporová (2019), who also talk about fathers' responsibilities, changes in perception and life, and changes in priorities, as well as limiting time for themselves.

\section{CONCLUSION}

The way to today's form of fatherhood has not been short and not always easy. Society's expectations, job requirements, family life, raising children, a relationship with a partner or personal internal conflicts - all of this is encountered by today's fathers and they must find ways to balance several areas of life. However, it is a natural process that comes with parenting and the family, and every father needs to find a place in it where he or she will feel comfortable and at the same time himself.

We can identify the current forms of fatherhood as diverse. There are fathers who are less involved in the family, but also fathers for whom family and children are everyone. Our research has shown that today we find more and more fathers, for whom fatherhood means a lot and they are very active in family life as well as in the lives of children. They no longer consider only family support as their main task and do not leave the care of children mainly to the mother. On the contrary, they perceive fatherhood as a mission, they want to be good fathers for their children and they realize the importance of time spent with children. They want to be close to the children who will accompany them through life into adulthood.

\section{REFERENCE LIST}

Brandth, B., Kvande, E. (1998). Masculinity and Child Care: The Reconstruction of Fathering. The Sociological Review [online]. 1998, roč. 46, č. 2, s. 293-313. ISSN 0038-0261, 1467-954X. doi:10.1111/1467-954X.00120 
Crespi, I., Ruspini, E. (2015). Transition to fatherhood: New perspectives in the global context of changing men's identities. International Review of Sociology [online]. 2015, roč. 25, č. 3, s. 353-358. ISSN 0390-6701, 1469-9273. doi:10.1080/03906701.2015.1078529

Filadelfiová, J., Kiczková, Z., Szapuová, M. (2006). Úloha mužov pri podpore rodovej rovnosti: participácia otcov na domácej starostlivosti (názory a skúsenosti populácie SR). 2006. B.m.: Slovenské národné stredisko pre ludské práva.

Johansson, T. (2011). Fatherhood in Transition: Paternity Leave and Changing Masculinities. In Journal of Family Communication [online]. 2011, roč. 11, č. 3, s. 165-180. ISSN 1526-7431, 1532-7698. doi:10.1080/15267431.2011.561137

John, W. St, Cameron C., Mcveigh, C. (2005). Meeting the Challenge of New Fatherhood During the Early Weeks. In Journal of Obstetric, Gynecologic \& Neonatal Nursing [online]. 2005, roč. 34, č. 2, s. 180 189. ISSN 08842175. doi:10.1177/0884217505274699

Lewis, L., Banmen, J. (2009). Pozitivní psychologie V. Satirové. In BANMEN, J. (ed.). 2009. Transformační systemická terapie. Ostrava : IVS ČR, s. 43-68, ISBN 978-80-254-4976-9.

Maříková, H. (2008a). Caring Fathers and Gender (In)Equality. Polish sociological review. 2008, č. 2, s. 135152. ISSN 1231-1413.

Maříková, H. (2008b). Rodičovská (je) pro oba rodiče! In KŘí̌KOVÁ, A., DUDOVÁ, R. 2008. Práce a péče: Proměny "rodičovské" $v$ České republice a kontext rodinné politiky Evropské unie. Praha: Sociologické nakladatelství (SLON). ISBN 978-80-86429-94-6.

Mclaughlin, K., Muldoon, O. (2014). Father Identity, Involvement and Work-Family Balance: An In-depth Interview Study: Father identity and work-family balance. In Journal of Community \& Applied Social Psychology [online]. 2014, roč. 24, č. 5, s. 439-452. ISSN 10529284. doi:10.1002/casp.2183

Miller, T. (2011). Making sense of fatherhood: gender, caring and work. New York, USA: Cambridge University Press. ISBN 978-0-521-74301-3.

MPSV ČR (2010). Podoby otcovství v ČR - sociologický výskum [online]. http://www.tatanaplnyuvazek.cz/wp-content/uploads/2013/05/zaverecna-zprava-podoby-otcovstvi.pdf

Nešporová, O. (2019). Hazy Transition to Fatherhood: The Experiences of Czech Fathers. In Journal of Family Issues [online]. 2019, roč. 40, č. 2, s. 143-166. ISSN 0192-513X, 1552-5481. doi:10.1177/0192513X18806028

Pleck, E. H., Pleck, J. H. (1997). Fatherhood ideals in the United States: Historical dimensions. V: M. E. LAMB, ed. In The role of the father in child development, 3rd ed. Hoboken, NJ, US: John Wiley \& Sons Inc, s. 33-48. ISBN 978-0-471-11771-1.

Trapková, L., Chvála, V. (2004). Rodinná terapie psychosomatických poruch. Praha : Portál, 227 s., ISBN 80-717-8889-9.

Vreeswijk, CH. et al. (2014). Fathers' experiences during pregnancy: Paternal prenatal attachment and representations of the fetus. Injohn Psychology of Men \& Masculinity [online]. 2014, roč. 15, č. 2, s. 129-137. ISSN 1939-151X, 1524-9220. doi:10.1037/a0033070 